УАK 327.8:327

ББК $66.49+66.4(4 / 8)$

DOI 10.22394/1682-2358-2018-3-46-52

A.Yu. Chikbachev, postgraduate student of the European Studies Department, Saint-Petersburg State University

\section{FOREIGN POLICY OF MODERN FRANCE: FEATURES \\ OF EMMANUEL MACRON'S DIPLOMATIC STYLE}

The main properties of Emmanuel Macron's diplomatic style are analyzed. The author compares them with the classic Gaullist approach to foreign policy issues. The dynamism and creativity of the new highest-level officials are particularly emphasized.

Key words and word-combinations: foreign policy of France, diplomatic style, Emmanuel Macron.
А.Ю. ЧихачеВ, аспирант кафедрь европейских исследований Санкт-Петербургского государственного университета (етаil: alexchikbachev@gmail.com)

\section{ВНЕШНЯЯ ПОАИТИКА СОВРЕМЕННОЙ ФРАНЦИИ: ОСОБЕННОСТИ АИПАОМАТИЧЕСКОГО СТИАЯ ПРЕЗИАЕНТА Э. МАКРОНА}

Аннотация. Анализируются особенности дипломатической активности нового Президента Франции Э. Макрона. Проводится сравнение с голлистским внешнеполитическим стилем. Подчеркиваются динамизм и инициативность нынешнего французского руководства, отличающие его от предшественников.

Ключевые слова и словосочетания: внешняя политика Франции, дипломатический стиль, Эммануэль Макрон.

$\Pi$ оабцюдению французского автора Ф. Шарийона, внешняя политика современной Франции подвержена дихотомии «разрывов» и преемственности [1, р. 1517]. В момент смены вмасти всегда возникает вопрос, сформулирует $и и$ новый хозяин Елисейского Аворца Аипломатический курс принщипиально иначе или будет придерживаться примерно тех же поАХоАОв и иАей, что и его преАшественник. Со времен основатемя Пятой Республики Шарця де Гоммя каждый президент по-своему решал эту 
дилемму, обычно сохраняя преемственность по наиболее принципиальным моментам и привнося нечто новое в деталях. Фигура Эммануэмя Макрона, заступившего на свой пост в мае 2017 г., придала новое звучание проблеме преемственности внешней политики Франџии с точки зрения стиця презиАентской власти. С самых первых дней своего мандата новый мидер начал демонстрировать определенные стилевые новации, аАаптируя практиковавшийся подход к принятию государственных решений под себя. Соответственно, все более актуальным становится вопрос, на каких принципах строится его

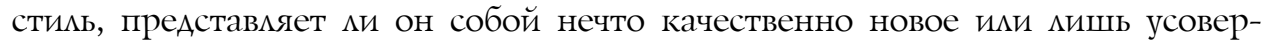
шенствует старые образцы.

Появление нового Президента Франции не могло не встретить живой отклик в академической среде - как российской, внимательно следившей за президентскими выборами 2017 г., так и зарубежной (прежде всего, естественно, французской). Отечественных авторов пока более всего интересует внутриполитический фон прихода Э. Макрона к власти. Так, крупнейший российский спеџиалист по франџузской тематике Ю.И. Рубинский удемяет основное внимание закономерностям партийно-политической системы Франции, в силу которых победа нового мидера оказалась возможной [2]. В том же кмюче рассуждают Р.В. Костюк [3], Т.В. Зверева [4] и Е.А. Осипов [5].

Такие авторы, как Е.О. Обичкина [6] ими В.Н. Чернега [7], упоминают о Аипломатическом курсе Президента несколько чаше, но имеют в виду не столько стилевые, сколько чисто содержательные изменения. Наибольший же акцент на дипломатическом стиле Э. Макрона как самостоятельном объекте изучения был слелан Т.А. Становой, попытавшейся определить, в какой манере новый глава государства будет действовать на международной арене [8].

В этом же направлении пытаются рассуждать и зарубежные авторы. СтиАю нового Президента время от времени посвящаются заметки и комментарии во Французском институте межАународных отношений (IFRI) [9], Институте межАународных и стратегических отношений (IRIS) [10], Европейском совете по международным отношениям (ECFR) [11], Chatham House [12] и т.А. Среди наиболее видных исследователей необходимо отметить Т. Гомара и П. Бонифаса [13] , видящих во внешней политике Э. Макрона не только набор конкретных действий, но и некий индивидуальный ПОАХОА.

Настоящая публикация призвана дополнить имеющиеся наработки российских авторов на тему президентского стиля Э. Макрона и выделить его наиболее заметные черты. Необходимо еще раз подчеркнуть, что исследование фокусируется прежде всего на его внешнеполитической ипостаси (Аипмоматическом стиле): именно в ней нынешний глава государства проявляет наибольшую мичную активность и озвучивает наиболее принципиальные положения. Кроме того, по Аавней традиџии франџузской политической жизни все президенты склонны считать внешнюю политику искАючительно своей «вотчиной» (по возможности, не Аелясь ей с Аругими властными 
институтами) [14, с. 90-94]. Таким образом, именно там следует искать их собственные установки и стилевые особенности в наиболее конџентрированном виде.

Исследуя политическую систему Пятой Республики, установленную по Конституции 1958 г., известный политолог М. Аюверже отметил, что она имеет виА своеобразной «республиканской монархии» [15] . С одной стороны, в стране сохраняются принщип распределения властей, выборные проџедуры и парламентское преАставительство. С Аругой стороны, власть первого миџа президента - настолько широка, что позволяет ему править практически единолично, подобно старинному монарху. При этом Аидер должен выдерживать определенный стиль: не злоупотреблять своими полномочиями для решения

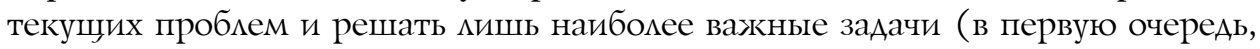
внешнеполитического плана); выполнять функцию нейтрального арбитра в спорах межАу Аругими институтами; быть «общенациональным» мидером, а не сторонником только одной партии.

Очевидно, что подобная модель сформировалась под влиянием первого Президента Пятой Респубцики Ш. де Гомля (1958-1969). В цеентре его поцитического проекта находилась так называемая «идея величия» - стреммение к повсеместному укреплению авторитета Франции, становлению ее как самостоятельного игрока в мире [14, с. 90-91]. Общему замыслу «вемичия» Аолжны были быть подчинены все Аействия правительства как внутри страны, так и за рубежом. Внешний образ главы государства, его манера принимать решения, вести переговоры, общаться с подчиненными также домжны были нести этот отпечаток. С точки зрения Ш. Ае Гомяя, президент, стремящийся к «величию» Франции и решающий самые серьезные задачи, подАерживает свой престиж с помощью некой таинственности: «Авторитет не может обойтись без тайны, ведь мы мало чтим то, что слишком хорошо понимаем. <..> Необходимо, чтобы в замыслах, манере держаться, Авижениях мысли авторитетного человека оставался элемент, не подАающийся пониманию Аругих, который их интриговал бы, волновал и держал в напряжении» [16, с. 100].

По мысли генерала, истинный мидер всегда берет всю ответственность за судьбу страны на себя; в этом ему помогают сила характера, воля, гордость, суровость в общении, изолированность от мюбых внешних наблюдателей. Государственные решения кидер принимает целиком самостоятельно, но обдуманно и на долгосрочную перспективу, отказываясь от погони за сиюминутным результатом или медиаэффектом. Все эти качества ярче всего проявлялись бы именно во внешней политике, где можно было наиболее полно заявить себя как «монарха», защищающего престиж Франџии. В голиистском представлении, «величие» страны всегда важнее, чем решение той или иной проблемы мюбой ценой (особенно ценой наџионального суверенитета). Первый Президент Пятой Республики неоднократно подтверждал этот тезис, например, всячески противясь усилению наАнациональных институтов европейской интеграџии в ущерб наџиональным правительствам. 
Аанным подходом руководствовался в своем дипломатическом курсе и сам Ш. де Гоммь, и его преемники, хотя те со временем отходили от его стиля все дальше. Так, Президент В. Жиискар-А'Эстен (1974-1981) впервые попытался сделать внешнюю политику менее зависящей от воли первого Аиџа, поощряя дискуссии о ней в правительстве [17, с. 154-155, 160-162] и приближая к себе карьерных дипломатов с профессиональным взглядом на вещи. Президент Ф. Миттеран (1981-1995) во многом вернулся к кмассическому гомиистскому стилю (отсюда возник термин «гомистско-миттерановская традиџия»), но периодически использовал внешнюю политику как средство борьбы с правой оппозицией в периоды «сосуществования» [14, с. 188, 205-206, 237] . В свою очередь, Ж. Ширак (1995-2007) бым вынужден адаптировать дипломатический стиль под реалии постбиполярного мира и не только заниматься «высокой политикой», как подразумевали гомлистские установки, но и, например, содействовать интересам французского бизнеса во время поездок за рубеж [14, с. 240] . В качестве явного прагматика позищионировац себя Н. Саркози (2007-2012) [18, с. 55-67], открывший внешнюю политику для широких общественных дискуссий (хотя и принимавший решения по-прежнему еАинолично) и де-факто сделавший ее частью своей внутриполитической борьбы. Наконеџ, Ф. Олманд пользовался стилем «обычного президента» [19], совсем не претендовавшего на «великий замысел», а рассчитывавшего на конкретные Аипломатические успехи. По большому счету, к 2017 г. голиистского Аипмоматического стиля в чистой форме уже не существовацо, и Э. Макрону оставалось продолжить попытки его переосмысления.

В первых же шагах нового Президента Франџии на международной арене начали проявцяться отличительные черты его стиля.

Во-первых, Э. Макрон сразу же задал для французской дипломатии крайне высокий темп, выраженный в значительном количестве международных визитов и встреч - и совершенно не сопоставимый с размеренным темпом «классического» голмизма. В первые недели после инаугураџии (14 мая 2017 г.) новый глава государства успец встретиться в Берлине с канулером ФРГ А. Меркель (15 мая), посетить расположение французских войск в Мали (19 мая), принять участие в саммитах НАТО (Брюссель, 24-25 мая), G7 (Таормина, 26-27 мая) и G20 (Гамбург, 7-8 июля). Весьма быстро были организованы встречи с В. Путиным (Версаль, 29 мая) и А. Трампом (1314 июля). За первый год мандата президенту удалось также добраться до Нью-Йорка (72-я Генассамблея ООН, 19-20 сентября), некоторых африканских столиц (турне 27-30 ноября), Пекина (7-8 января 2018 г.), НьюАеми (10-12 марта), Вашингтона (23-25 апреля) и Москвы (24-25 мая), не говоря о многочисленных визитах в пределах Европейского союза. Тем самым Э. Макрон в кратчайшие сроки набрал определенный дипломатический вес, установив контакты с крупнейшими международными игроками и попытавшись АОнести АО них своИ ВзгАяды.

Во-вторых, резко выросла степень иниџиативности внешней политики 
Франции на самых разных направлениях. Аействующий Президент уже отметился рядом идей, привлекших внимание как прессы, так и зарубежных партнеров. Среди основных уместно назвать:

- идею «Аиалога Трианона, озвученную на встрече с В. Путиным в Версале;

- запуск инициативы «Make Our Planet Great Again» после выхода США из Парижского соглашения по кмимату (1 июня 2017 г.);

- учреждение совместного воинского контингента в зоне Сахеля на саммите «сахельской пятерки» (Бамако, 2 июля 2017 г.);

- оглашение плана по реформированию Европейского союза (Париж, 26 сентября 2017 г.);

- попытки урегулировать кризисы в Аивии и Аиване (переговоры кивийских мидеров в Сель-Сен-Кцу 25 июля и встреча с С. Харири 18 ноября 2017 г.).

В основе всех этих шагов межали главные качества президента - энергичность, амбициозность, стремление добиваться быстрых результатов. Не следует забывать, что до высшего государственного поста карьера Э. Макрона проходика в мире экономики и бизнеса [4], где подобные черты характера в немалой степени способствуют успеху. К ним же относится гибкость мышиения, готовность найти новый метоА решения проблемы вместо уже не работаюшего старого. Именно поэтому, например в отношениях с Россией, Э. Макрон не придерживается одной и той же принципиальной позиции, как Ф. Омланд в 2014-2017 гг., а пробует искать новые возможности, укрепцяя контакты с российской стороной посредством «АиаАога Трианона» и визита на Петербургский межАународный экономический форум (24-26 мая 2018 г.).

Правда, скмонность Президента Франџии постоянно выдвигать новые предложения имеет и обратную сторону. Аостигаемый по ним результат, преподносимый в прессе как Аипломатический прорыв, по факту может оказаться весьма условным и требующим дополнительных усилий. Такая ситуащия набцюдалась по вопросу создания совместных вооруженных сиц стран Сахельского региона (Мавритания, Мали, ЧаА, Нигер, БуркинаФасо), обсуждавшегося с 2015 г. Э. Макрону удалось уговорить кидеров «сахельской пятерки» выделить силы и средства для общего контингента, но реальное взаимодействие частей на поле боя оставлямо желать кучшего [20]. С немалым трудом удалось найти внешних спонсоров, готовых взять на себя финансирование этого проекта, - ЕС, США, Саудовскую Аравию, ОАЭ [21].

Наконец, в-третьих, курс Э. Макрона не имеет четкой доктринальной привязки к идее «величия» Франщии. В своих разнообразных заявмениях глава государства формулирует внешнеполитические џели весьма Авойственно: следование национальным интересам сосеАствует с защитой миберальных ценностей по всему миру, подАержание «стратегической автономии» страны увязывается с планами укрепления евроатлантической солидарности, желание развивать связи с Россией не уступает периодичес- 
кой критике ее действий. В связи с этим от нового Президента уже не требуется походить на Ш. де Гомля или Ф. Миттерана и вести себя под стать единожды сформулированному «великому замыслу». Аостаточно выбрать ту манеру поведения, которая обеспечит достижение точечных результатов в данный момент времени, приведет к укреплению международной роли Франщии вне зависимости от того, будет ми это называться «величием». Иначе говоря, Э. Макрон не связывает себя какой-либо строгой концепцией, формулируя вместо нее отдельные «коридоры допустимого» [8] и гибко действуя в их рамках.

Следует заключить, что дипломатический стиль первых миџ французской внешней политики сегодня серьезно отличается от стандартов полувековой давности. Пишется новый портрет президента Пятой Республики: вместо умудренного опытом «монарха», преисполненного чувством ответственности и «вемичия» наџии и неуклонно следуюшего строгим принџипам, теперь это энергичная современная фигура, постоянно предлагающая новые идеи и ишушая скорейших результатов. Вместе с тем пока невозможно утвержАать, что в стилевом отношении произошел полный «разрыв» с прошлым, а Э. Макрон предложиц некую законченную модель власти. Как минимум, она должна доказать свою жизнеспособность на протяжении всего мандата, а не только Аишь одного года. Сохраняется и главный эмемент преемственности с временами Ш. де Гомля: руководство внешней политикой Франџии по-прежнему напрямую зависит от воли и убеждений первого мица. Тем не менее новый Президент делает серьезный шаг в сторону качественного обновмения гомиистского стиля - его аАаптации поА сегоАняшние внутриполитические и межаународные реалии.

\section{Библиографический список}

1. Charillon F. La politique étrangure de la France. Paris: La documentation Française, 2011.

2. Рубинский Ю. Франция: прощание с биполярностью? // Аналитическая записка / Институт Европы РАН. 2018. № 14.

3. Костюк Р.В. Политическое противостояние во Франции накануне президентских выборов 2017 года // Конфликтология. 2017. № 1. С. 90-101.

4. Зверева T.В. Эмманюэль Макрон: политический портрет // Вестник Дипломатической академии МИД России. Россия и мир. 2017. № 2 (12). С. 21-32.

5. Осипов E.A. Между несчастной и счастливой идентичностью. Франция в поисках себя // Политика и общество. 2017. № 11. С. 55-62.

6. Обичкина Е. Франция - Германия: проблемы европейского тандема // Российский совет по международным делам. URL: http://russiancouncil.ru/analytics-and-comments/analytics/frantsiya-germaniya-problemy-evropeyskogo-tandema/

7. Чернега В.Н. Макрон и внешняя политика Франции: между прошлым и будущим // Европейская безопасность: события, оценки, прогнозы. 2017. № 46 (62). С. $2-5$.

8. Становая T. Либеральный голлизм. Как строится новая внешняя политика Франции // Московский Центр Карнеги. URL: https://carnegie.ru/commentary/72741

9. Gomart T. La politique étrangure d'Emmanuel Macron: retour au réalisme? (Entretien avec la Revue des Deux Mondes) / IFRI. URL: https://www.ifri.org/fr/espace-media/lifri-medias/politiqueetrangere-demmanuel-macron-retour-realisme 
10. Dungan N. Emmanuel Macron and the Sense of Reality / IRIS. URL: http://www.iris-france. org/97109-emmanuel-macron-and-the-sense-of-reality/

11. Rapnouil M.L., Shapiro J. Macron's Foreign Policy: Claiming the tradition / ECFR. URL: http://www.ecfr.eu/article/commentary_macrons_foreign_policy_claiming_the_tradition_7285

12. Conte M. le. Macron is still airborne // Chatham House. The World Today. February \& March, 2018.

13. Diplomatie: pour Pascal Boniface, Macron se revendique du gaullo-mitterandisme // RCF Radio. 2017. 29 aout. URL: https://rcf.fr/actualite/diplomatie-pour-pascal-boniface-macron-se-revendique-du-gaullo-mitterandisme

14. Обичкина E.O. Внешняя политика Франции от де Голля до Саркози (1940-2012). М., 2012.

15. Duverger M. La Monarchie républicaine - ou comment les démocraties se donnent des rois. Paris: Robert Laffont, 1974.

16. Голль Ш. де. На острие шпаги. М., 2006.

17. Жискар-д'Эстен В. Власть и жизнь. М., 1990.

18. Рубинский Ю.И. Франция. Время Саркози. М., 2011.

19. 2012. Le débat: François Hollande face a Nicolas Sarkozy / Institut national de l'audiovisuel. URL: http://www.ina.fr/video/4701149001

20. Berthemet T. La difficile mise au point du G5 Sahel // Le Figaro. 2018. 14 janvier. URL: http://www.lefigaro.fr/international/2018/01/14/01003-20180114ARTFIG00147-la-difficile-miseau-point-du-g5-sahel.php

21. Bozonnet C. Emmanuel Macron obtient un soutien accru pour le G5 Sahel // Le Monde. 2017. 14 decembre. URL: http://www.lemonde.fr/afrique/article/2017/12/14/emmanuel-macron-obtientun-soutien-accru-pour-le-g5-sahel_5229336_3212.html 